\title{
Climate-driven changes in sedimentation rate influence phosphorus burial along continental margins of the northwestern Mediterranean
}

\author{
Aleix Cortina ${ }^{\mathrm{a}, \mathrm{d}, *}$, Gabriel Filippelli ${ }^{\mathrm{b}}$, Diana Ochoa $^{\mathrm{c}}$, Francisco Javier Sierro ${ }^{\mathrm{d}}$, José-Abel Flores ${ }^{\mathrm{d}}$, \\ Joan O. Grimalt ${ }^{\mathrm{a}}$

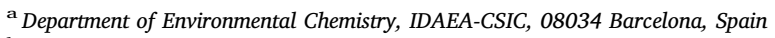 \\ ${ }^{\mathrm{b}}$ Department of Earth Sciences, Indiana University-Purdue University Indianapolis (IUPUI), Indiana, USA \\ ${ }^{\mathrm{c}}$ Biogeosciences Lab - FCF-CIDIS - Universidad Peruana Cayetano Heredia, Peru \\ d Department of Geology, University of Salamanca, 37008 Salamanca, Spain
}

\section{A R T I C L E I N F O}

\section{Keywords:}

Paleoredox

Phosphorus paleoproductivity

Gulf of lions

Termination IV

MIS 8

\begin{abstract}
A B S T R A C T
The burial of phosphorus $(\mathrm{P})$ in continental margin sediments is a critical component of the marine reactive $\mathrm{P}$ budget, and thus an important factor in marine biological productivity. We determined downcore records of $\mathrm{P}$ from a site drilled on the upper slope of the Gulf of Lions (PRGL 1), northwestern Mediterranean Sea. Changes in total P content were monitored from Marine Isotope Stage (MIS) 6 to MIS 11. In addition, in two selected intervals (248-277 ka and 306-342 ka) the total P record was expanded by adding detailed geochemical analyses of the various $\mathrm{P}$ fractions, including oxyhydroxide-associated $\mathrm{P}$, authigenic $\mathrm{P}$, detrital $\mathrm{P}$ and organic $\mathrm{P}$.

Increased sedimentation rates during glacials owing to seaward migration of the Rhone's mouth, enhanced the burial of reactive $\mathrm{P}$ (oxyhydroxide-associated + authigenic + organic) phases by decreasing its time at the reactive sediment/water interface, in turn resulting in increasing proportion of authigenic to detrital phosphorus. The inverse was found for interglacial stages. The effects of glacial/interglacial variation in sedimentation rate over $\mathrm{P}$ geochemistry resulted in changes in sediment-water interface oxygenation, as well as in the efficiency of $\mathrm{P}$ burial, as shown by $(\mathrm{C}: \mathrm{P})_{\text {org }}$ and $\mathrm{C}_{\text {org }}: \mathrm{P}_{\text {react }}$ proxies respectively.

Two events of high $\mathrm{P}$ deposition associated with authigenic $\mathrm{P}$ formation, at $335 \mathrm{ka}\left(\mathrm{P}_{\text {aut1 }}\right)$ and $275 \mathrm{ka}\left(\mathrm{P}_{\text {aut } 2}\right)$, were associated with periods of rapid disintegration of North Atlantic ice sheets leading to Ice Rafted Debris (IRD) deposition. These high P deposition events appear to be linked to short warm periods that followed cold episodes. Enhanced continental runoff owing to more humid conditions during short warm episodes could play a critical role for enhanced biogenic productivity and posterior authigenic $\mathrm{P}$ accumulation.
\end{abstract}

\section{Introduction}

Marine primary productivity is influenced by the availability of key nutrients such as nitrogen (N) and phosphorus (P) (Raymont, 1980). Phosphorus has been proposed as the ultimate limiting nutrient of oceanic production, owing to the ability of pelagic cyanobacteria to fix $\mathrm{N}$ from the atmosphere, thus offsetting any $\mathrm{N}$ deficit (Tyrrell, 1999). In fact, in the Mediterranean, P availability has been shown as a limiting factor of the primary productivity (Krom et al., 1991). Despite the physiologic importance of $\mathrm{P}$ to photosynthetic plankton, its availability to organisms in the marine realm is constrained because sources are limited to atmospheric and river influx (Ruttenberg, 2003), and bioavailability is limited by rapid sequestration in different phases (Filippelli, 2008). When assimilated by organisms, $\mathrm{P}$ is incorporated into an organic pool $\left(\mathrm{P}_{\text {org }}\right)$. In most marine environments, the $\mathrm{P}$ pool exported to the sea floor is dominated by $\mathrm{P}_{\text {org }}$, while oxyhydroxideassociated $\mathrm{P}\left(\mathrm{P}_{\mathrm{oxy}}\right)$ is of similar magnitude in continental margin environments with significant amounts of terrigenous material input (Filippelli and Delaney, 1996).

The fate of $\mathrm{P}$ relative to carbon (C) appears to be controlled by oxygen availability in bottom waters. Phosphorus retention in sediments is enhanced by high oxygen content, whereas the contrary is valid for C (Pratt, 1984). Differences in P retention between oxic and anoxic bottom conditions are explained by two mechanisms: (1) redoxdependent changes in the physiology of microorganisms in sediments, and (2) benthic phosphate cycling associated with reactive Fe oxide phases (Van Cappellen and Ingall, 1994). In aerobic environments microorganisms actively accumulate and store $\mathrm{P}$ as polyphosphates (Toerien et al., 1990). Once oxygen is depleted, the P stored by bacteria is used as an energy source and released as dissolved phosphate to the

\footnotetext{
* Corresponding author.

E-mail address: acortina@usal.es (A. Cortina).
} 
environment. This mechanism has been observed in several bacterial genera and in protozoans (e.g. Shapiro, 1967; Toerien et al., 1990). Bacteria may also accumulate phosphate under anoxic conditions, however, the storage rate is much slower than under aerobic conditions (Kerrn-Jespersen and Henze, 1993). A second mechanism of P retention enhancement is linked to $\mathrm{Fe}$ (oxyhydr) oxides, and is only operative in sediments overlain by oxygenated bottom waters. It involves the scavenging of phosphate produced during organic matter degradation during oxidative Fe precipitation (Berner, 1973). Such mechanisms of differential control on $\mathrm{P}_{\text {org }}$ and $\mathrm{C}$ retention in marine sediments due to oxygenation levels allow us to use them as paleoredox tracers (Algeo and Ingall, 2007). Two key factors also influence the use of (C:P) tracer of redox conditions: (i) sedimentation rate have been demonstrated to affect $(\mathrm{C}: \mathrm{P})_{\text {org }}$, decreasing this ratio when sedimentation rate increases (Slomp and Van Cappellen, 2007), and (ii) diagenetic alteration of the main source of $\mathrm{C}$ and $\mathrm{P}_{\text {org }}$ (i.e. organic matter) may occur (Anderson et al., 2001).

Once in the sediment, progressive burial of labile forms of $\mathrm{P}$ (i.e., $\mathrm{P}$ bound to organic matter and iron oxides) may be partially or completely transformed through precipitation of $\mathrm{Ca}$ phosphate minerals into stable $\mathrm{Ca}-\mathrm{P}$ authigenic apatite (Froelich et al., 1988). This process of "sink switching" constitutes the principal long-term sedimentary sink of non-detrital P (Anderson et al., 2001). Therefore, reactive $P\left(P_{\text {react }}\right)$ best represents the geochemical behavior of sedimentary P. $\mathrm{P}_{\text {react }}$ consists in the sum of organic, oxide associated and authigenic forms (Ruttenberg, 1992, 1993), neglecting detrital $\mathrm{P}\left(\mathrm{P}_{\mathrm{det}}\right)$, which enters and exits the marine system with little or no geochemical interaction with seawater. Hence, the use of the $C_{\text {org }}: P_{\text {react }}$ can be indicative of the overall $\mathrm{P}$ retention efficiency in the sediment, accounting for sink switching from organic matter to mineral phases.

Continental margin sediments, in particular off major river mouths, are important for the burial and diagenetic transformation of $\mathrm{P}$, yet how the dynamic depositional conditions in these settings affect sedimentary $\mathrm{P}$ cycling is poorly documented. Comprehensive analyses of $\mathrm{P}$ burial in continental margins are challenging to carry out as a consequence of local variability in productivity, the strong effect of sea-level changes on sedimentation rates during glacial/interglacial periods, and sediment reworking (Filippelli and Delaney, 1995). The Gulf of Lions, located south-west of the Rhone delta, is an example of such riverdominated continental margins, and its sedimentary record has been demonstrated as suitable for reconstructing past climate variability over long (Bassetti et al., 2006; Berne et al., 2007) and short (Sierro et al., 2009; Frigola et al., 2012) timescale, which makes it appropriate to evaluate the climate impact on $\mathrm{P}$ burial in a continental margin.

The Mid-Brunhes Event (MBE) placed at $430 \mathrm{ka}$, marks the beginning of the strongest glacial/interglacial variability following the 100kyr cycle during Quaternary (Lang and Wolff, 2011). While many paleoclimate studies are focused in the first two climate cycles (MIS 1MI5), further research needs to be carried out from MIS 6 to 11 where intense glacial/interglacial variability is observed. In this work, we reconstruct $\mathrm{P}$ variability at the upper slope of the Gulf of Lions from MIS 6 to MIS 11. Phosphorus components were additionally extracted at greater detail during two periods between MIS 8 and 10 (from 306 to $342 \mathrm{ka}$ (MIS 9-10) and from 248 to $277 \mathrm{ka}$ (MIS 8)). For these intervals, P components were individually analyzed to assess: (1) the effect of sea level on sedimentation rates which in turn determines the degree of protection of $\mathrm{P}$ against degradation, and (2) atmospheric dynamics via intensification/reduction of northwesterly winds that impacts on water mixing and consequently the amount of oxygen that reaches sea floor. Examination of P components will shed light on P burial during (i) a full interglacial (MIS 9), (ii) a transition from glacial to interglacial conditions (Termination IV), (iii) and a significant transition between cold and warmer conditions during MIS 8 (Cortina et al., 2015). These new data will contribute to a better understanding of the controls of P cycling in the northwestern Mediterranean Sea.

\section{Regional setting}

The Mediterranean Sea has an anti-estuarine circulation owing to its negative water budget (precipitation - evaporation $<0$, which results mostly in oligotrophic conditions (Béthoux, 1979). There are however some regions with eutrophic conditions due to their hydrographic conditions (i.e. Gulf of Lions). The Gulf of Lions is one of the most productive areas in the Western Mediterranean Sea owing to vertical mixing in winter, upwelling events, and nutrient input from the Rhône (Lefèvre et al., 1997). The study area is situated southwest of the Rhone delta, where about half of the total biological productivity is driven by riverine input of nutrients (Lefèvre et al., 1997).

The Gulf of Lions plays an important role in the general circulation of the Mediterranean Sea, since it is the source of Western Mediterranean Deep Water (WMDW) as a consequence of the cooling and sinking of Modified Atlantic Water (MAW) (Millot, 1990). Dense water formation also occurs on the shelf, where during winters dry and cold northwesterly wind events are prolonged and surface waters on the continental shelf become denser and sink leading to cascading dense shelf water (CDSW) (Canals et al., 2006).

Ocean circulation in this region is mainly driven by the geostrophic Northern Current (NC), which is divided into two branches (Millot, 1990). The principal branch flows through the open sea along the Catalano-Balearic Sea, and a secondary branch occasionally circulates along the continental shelf edge, modifying the biogeochemistry by changing nutrient concentration of waters (Rubio et al., 2009) (Fig. 1).

The core site studied herein (PRGL1) is located on the upper slope of the Gulf of Lions (Fig. 1), which allows the study of P geochemistry under two different scenarios in terms of sedimentation rate owing to glacial/interglacial sea-level variability. Accommodation space is defined as the volume available to store sediment and water in the continental shelf. During glacial stages, sea-level drops produced a rapid progradation of the deltaic system, reducing the accommodation space and consequently increasing sedimentation rate. In contrast, sea level rises during deglaciation periods (e.g. Holocene) promoted a rapid retrogradation of the deltaic system from the outer to the inner shelf, increasing the accommodation space in the continental shelf, that caused a decrease in sedimentation rate (Bassetti et al., 2006; Berne et al., 2007) and nutrient availability along the upper slope. This nutrient dilution was additionally enhanced by influence of the North Current (NC) and the Mistral wind (i.e., wind effect on shape and extension of river plume; Morel and André, 1991).

\section{Methodology}

The borehole PRGL1 was drilled during the Promess1 campaign (summer 2004) in the Gulf of Lions $\left(42.690^{\circ} \mathrm{N}, 3.838^{\circ} \mathrm{E}\right.$ ) (Fig. 1) on the interfluve of the Boucart and Herault canyons at a water depth of $298 \mathrm{~m}$. The location of this site, near the shelf break, provides the potential for monitoring glacial-to-interglacial changes in sediment supply from the Rhone. This area provides excellent preservation of continuous sedimentary records because of the balance between the sedimentation rates and the accommodation space. Moreover, it is not influenced by the Rhone deltaic system and is distant from the Catalonian Margin, where erosive processes have taken place (Rabineau et al., 2005).

Cores were split and $1 \mathrm{~cm}$ thick slices were taken every $10 \mathrm{~cm}$. After constructing the age model, samples were selected for analysis with the objective of obtaining a millennial-scale temporal resolution. This goal was accomplished during glacial stages, with typical sedimentation rate above $1 \mathrm{~m} * \mathrm{kyr}^{-1}$ (Sierro et al., 2009); however, during interglacials the resolution was usually lower due to lower sedimentation rate (i.e. $<0.05 \mathrm{~m} * \mathrm{kyr}^{-1}$ ) (Sierro et al., 2009).

\subsection{Age model}

From 73.50 to $157.10 \mathrm{mbsf}$, we used the age model published by 


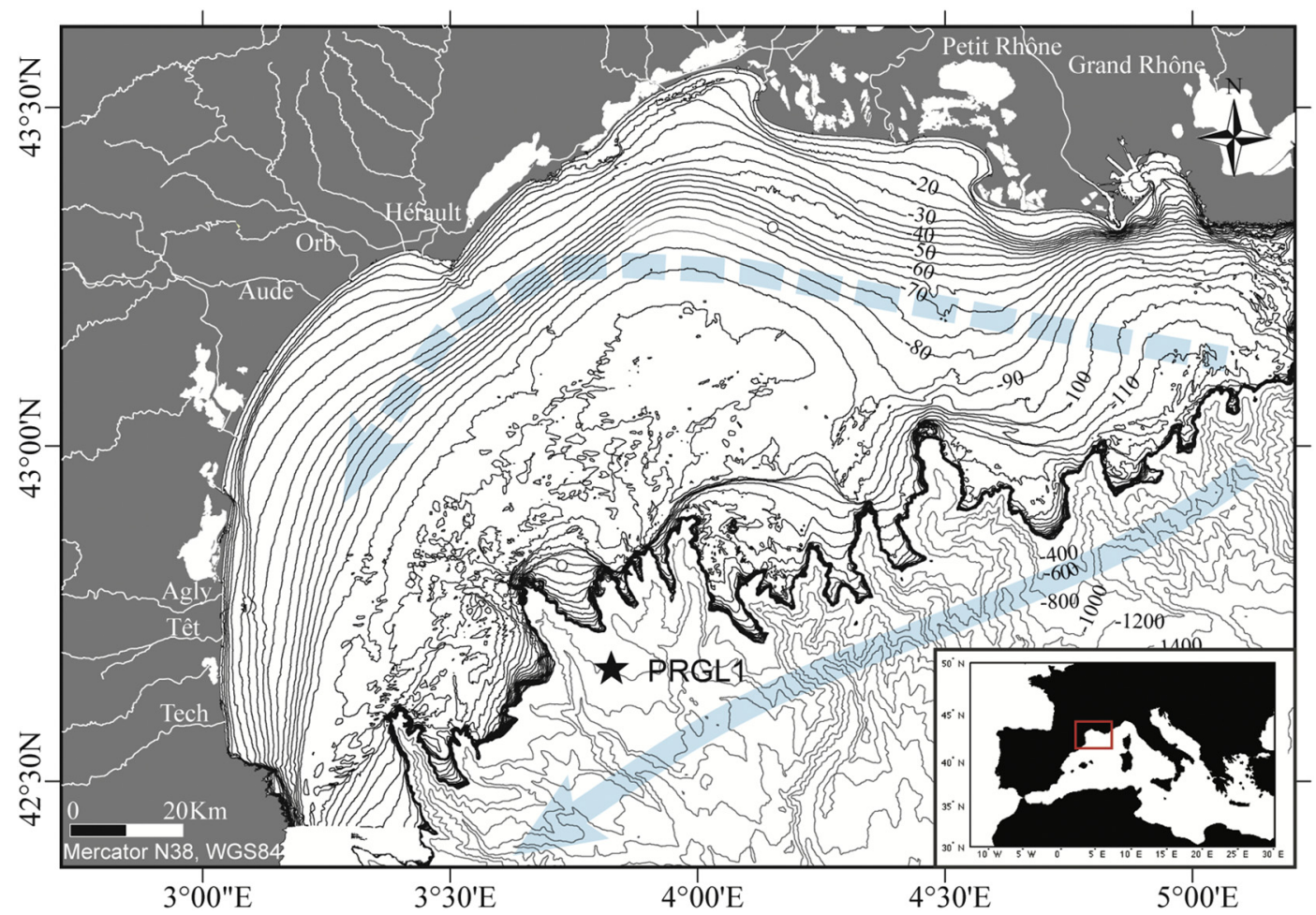



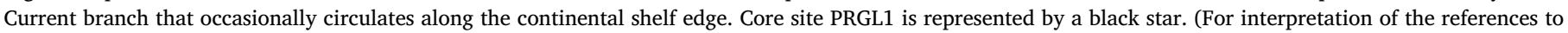
color in this figure legend, the reader is referred to the web version of this article.)

Sierro et al. (2009). For the second interval (from 157.10 to $210 \mathrm{mbsf}$ ) we used the age model published by Frigola et al. (2012). In both cases, the age model was mainly based on comparison of the G. bulloides $\delta^{18} \mathrm{O}$ record with a stack of 57 globally distributed benthic $\delta^{18} \mathrm{O}$ records (LR04 stack) (Lisiecki and Raymo, 2005), with the exception of the upper part where the isotope record was tuned to Greenland Ice cores. The calculated sedimentation rate resulted in an average sampling resolution of $1150 \mathrm{yr}$ during interglacials and $160 \mathrm{yr}$ during glacial stages.

\subsection{Elemental analysis}

A total of 240 samples were analyzed from 73.50 to $210 \mathrm{mbsf}$ (128-422 ka) in order to determine $\mathrm{P}, \mathrm{Fe}, \mathrm{S}$ and Ti concentration in bulk sediment. For carrying on the analysis, $0.1 \mathrm{~g}$ of each sample was dissolved using a MDS 2000 Microwave Digestion System and concentrated trace metal grade $\mathrm{HNO}_{3}, \mathrm{HF}$ and $\mathrm{HCl}$. After digestion was completed, boric acid was added to stabilize the solutions. The samples were transferred to new $50 \mathrm{ml}$ polypropylene centrifuge tubes and diluted to $50 \mathrm{ml}$ double deionized water. To determine total concentrations a Perkin-Elmer iCAP 6000 Inductively Coupled Plasma-Optical Emission Spectrometer, with high speed, high-resolution double monochromator with CCD array detector was used. Concentrations were determined from the measured intensities through standard curves. Additionally, we used a NIST marine sediment sample (Standard Reference Material 2702) through the entire digestion and analysis to ensure quality control of the process. Our net values agreed within $5 \%$ of the NIST standard for P and S, and within $2 \%$ for Ti and Fe.

\subsection{Phosphorus sequential extraction}

In order to elucidate $\mathrm{P}$ geochemistry in these sediments, a sequential extraction technique was used (Filippelli, 2001), which is a modified version of the SEDEX technique developed by Ruttenberg (1992). This technique isolates P from four sedimentary components depending on the dissolution characteristics of the components and on the optimized reagent strengths, reaction order, and reaction times. The four extracted components are: $(1)$ oxyhydroxide-associated $\mathrm{P}\left(\mathrm{P}_{\text {oxy }}\right)$, adsorbed onto or co-precipitated with easily reducible iron oxides and/or oxyhydroxides, (2) authigenic P-rich minerals and biogenic debris $\left(\mathrm{P}_{\text {aut }}\right),(3)$ detrital $\mathrm{P}$ $\left(\mathrm{P}_{\text {det }}\right)$ that is associated with detrital fluorapatite, as well as certain clays and any residual phase not dissolved in weak acid, and (4) organic $\mathrm{P}\left(\mathrm{P}_{\mathrm{org}}\right)$, associated with organic matter.

Details of the sequential extraction technique have been thoroughly documented before (Ruttenberg, 1992; Filippelli and Delaney, 1995), hence they will be simply summarized here. Two replicates of dry sediment weighing $0.5 \mathrm{~g}$ each were used. The first step, which isolated oxyhydroxide-associated $\mathrm{P}$, involved treatment of the solid sample with a solution consisting of $0.22 \mathrm{M}$ sodium citrate, $1 \mathrm{M}$ sodium bicarbonate, and $0.13 \mathrm{M}$ sodium dithionite for $6 \mathrm{~h}$, followed by subsequent treatments of $1 \mathrm{M} \mathrm{MgCl}_{2}$ and $\mathrm{H}_{2} \mathrm{O}$ for $2 \mathrm{~h}$ each. In the second step, which isolated authigenic and biogenic $\mathrm{P}$, the residual solid was treated with $1 \mathrm{M}$ sodium-acetate (buffered to $\mathrm{pH} 4$ with acetic acid) for $5 \mathrm{~h}$, followed by two treatments of $1 \mathrm{M} \mathrm{MgCl}_{2}$ and one treatment of $\mathrm{H}_{2} \mathrm{O}$ for $2 \mathrm{~h}$ each. In the third step, which isolated detrital $\mathrm{P}$, the residual solid was treated with $1 \mathrm{M} \mathrm{HCl}$ for $16 \mathrm{~h}$. In the fourth and final step, which isolated organically bound $\mathrm{P}$, the residual solid was dried at $60{ }^{\circ} \mathrm{C}$ with $50 \%(\mathrm{w} / \mathrm{v})$ $\mathrm{MgCl}_{2}$ solution, ashed at $550^{\circ} \mathrm{C}$ for $2 \mathrm{~h}$, then treated with $1 \mathrm{M} \mathrm{HCl}$ for $24 \mathrm{~h}$. For all steps other than oxyhydroxide-associated P, the standard ascorbic acid molybdenum blue technique (Strickland and Parsons, 1972) was used for developing color. Sample absorbances and P concentration calculations were performed using a Shimadzu UV-2101PC scanning spectrophotometer with a computer interface and a Sipper 260 autosipper attachment. Sample absorbances were zeroed versus double deionized water and measured at $885 \mathrm{~nm}$ with a slit width of $5 \mathrm{~nm}$. Reagent blanks and standards were prepared to be equivalent to the matrix of each sample step analyzed. Inductively Coupled PlasmaOptical Emission Spectrometer (a Perkin Elmer iCAP 6000 Emission 


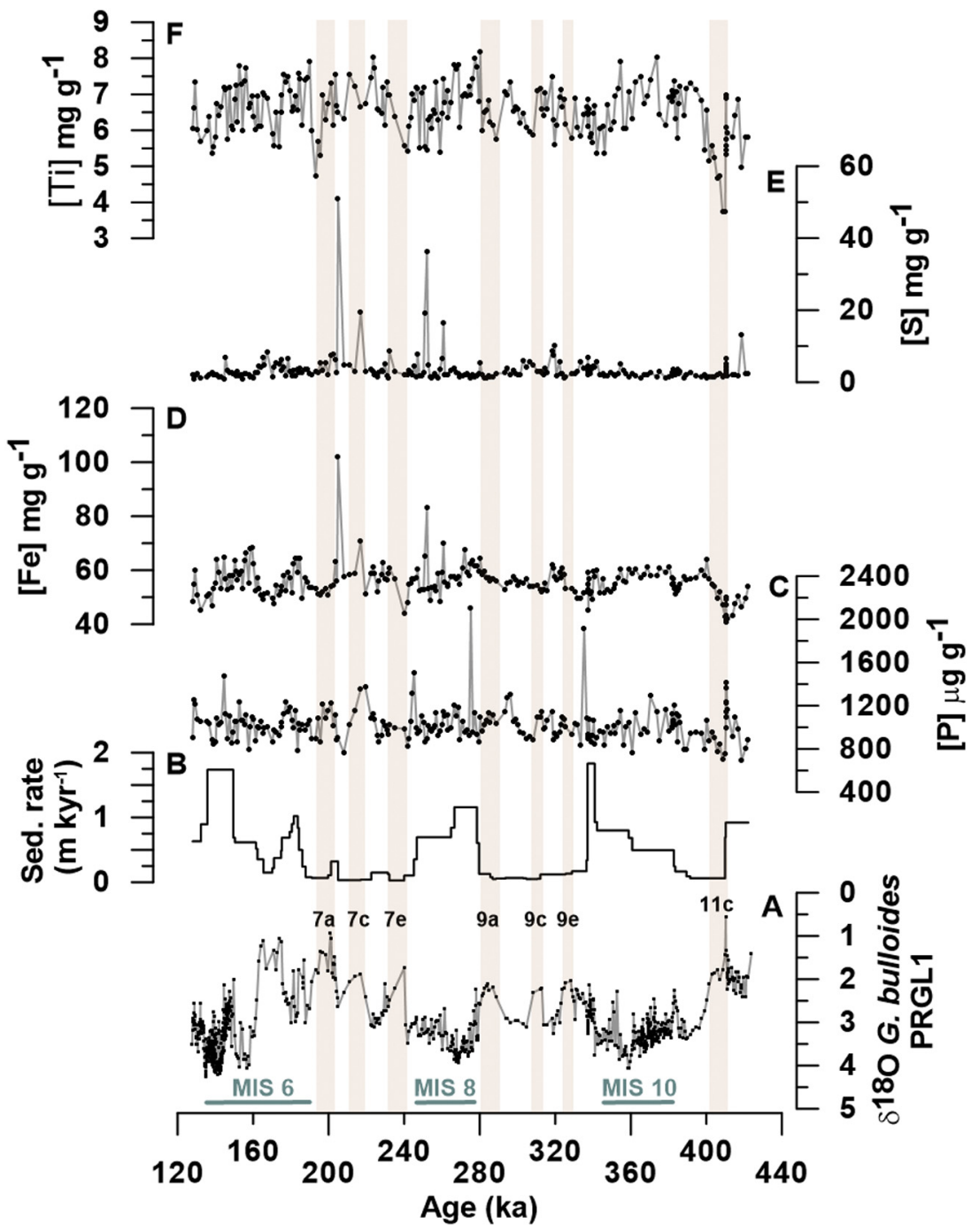

Fig. 2. Variations in phosphorus deposited in the upper slope of the Gulf of Lions from MIS 6 to MIS 11. A Globigerina bulloides $\delta{ }^{18} \mathrm{O}$ values. The values from $125 \mathrm{ka}$ to $265 \mathrm{ka}$ were taken from Sierro et al. (2009), while values from $266 \mathrm{ka}$ to 425 ka were taken from Frigola et al. (2012). B Sedimentation rate in PRGL1 $\left(\mathrm{m} * \mathrm{kyr}^{-1}\right)$. C Total phosphorus (P) concentration $\left(\mu \mathrm{g} \mathrm{g}^{-1}\right)$. D Total iron ( $\left.\mathrm{Fe}\right)$ concentration $\left(\mathrm{mg} \mathrm{g}^{-1}\right)$. E Total sulfur (S) concentration $\left(\mathrm{mg} \mathrm{g}^{-1}\right)$. F Total titanium (Ti) concentration $\left(\mathrm{mg} \mathrm{g}^{-1}\right)$. Orange bars depict warmer substages. (For interpretation of the references to color in this figure legend, the reader is referred to the web version of this article.)

Spectrometer) was used to determine oxyhydroxide-associated $\mathrm{P}$, since citrate-dithionite buffer used for this extraction interferes with the reduction of the molybdate P complex. The analytical reproducibility for $\mathrm{P}$ fractions was assessed through comparison to a long-term pooled marine sediment sample (Filippelli and Delaney, 1996). Total accuracy using this comparison is typically $\mathbf{5 - 8 \%}$ (Latimer and Filippelli, 2001).

\section{Results}

\subsection{Elemental analysis in bulk sediments}

The average $\mathrm{P}$ concentration in sediments was $1020 \mu \mathrm{gg}^{-1}$ (SD: $150 \mathrm{\mu g} \mathrm{g}^{-1}$ ), remaining remarkably stable between 800 and $1250 \mathrm{\mu g} \mathrm{g}^{-1}$ regardless of glacial/interglacial conditions (Fig. 2A,C). Two well-defined maxima were monitored around $275 \mathrm{ka}$ $\left([\mathrm{P}]=2100 \mu \mathrm{g} \mathrm{g}^{-1}\right)$ and $335 \mathrm{ka}\left([\mathrm{P}]=1920 \mu \mathrm{g} \mathrm{g}^{-1}\right)$ (Termination IV). Other less intense maxima were assessed with values above $1300 \mu \mathrm{g} \mathrm{g}^{-1}$ during Termination III ( $\left.[\mathrm{P}]=1520 \mu \mathrm{g} \mathrm{g}^{-1}\right), 7 \mathrm{~d} / 7 \mathrm{c}$ transition $\left([\mathrm{P}]=1360 \mu \mathrm{mol} \mathrm{g}^{-1}\right)$ and Interglacial MIS $11 \mathrm{c}$ $\left([\mathrm{P}]=1390 \mu \mathrm{g} \mathrm{g}^{-1}\right)$.

The average Fe concentration was $55.7 \mathrm{mg} \mathrm{g}^{-1}$ (SD: $6.1 \mathrm{mg} \mathrm{g}^{-1}$ ), showing strong millennial scale variability mainly during glacial stages (i.e. MIS 6, 8 and 10) (Fig. 2D). It tended to increase during cold stages marked by heavy ${ }^{18} \mathrm{O} G$. bulloides values, and to decrease during warmer periods. Minimum values were reached during interglacials MIS $7 \mathrm{e}$ and $11 \mathrm{c}$, and in a lesser extent during MIS 9e; whereas, distinctive maxima were monitored during MIS 7b, 7c, 8 and 9d. On the other hand, the average $S$ concentration was $3.5 \mathrm{mg} \mathrm{g}^{-1}$ (SD: $4.5 \mathrm{mg} \mathrm{g}^{-1}$ ). The values ranged mainly between 1.6 and $6.4 \mathrm{mg} \mathrm{g}^{-1}$. Five distinctive maxima concurring with maximum values of Fe were monitored during MIS $7 \mathrm{~b}\left([\mathrm{~S}]=51 \mathrm{mg} \mathrm{g}^{-1}\right), 7 \mathrm{c}\left([\mathrm{S}]=19.6 \mathrm{mg} \mathrm{g}^{-1}\right), 8$ $\left([\mathrm{S}]=36.2 \mathrm{mg} \mathrm{g}^{-1}\right.$ and $\left.22.9 \mathrm{mg} \mathrm{g}^{-1}\right)$ and $9 \mathrm{~d}\left([\mathrm{~S}]=10.1 \mathrm{mg} \mathrm{g}^{-1}\right)$ (Fig. 2E). Finally, the average concentration of Ti was $6.5 \mathrm{mg} \mathrm{g}^{-1}$ (SD: $0.7 \mathrm{mg} \mathrm{g}^{-1}$ ), with values ranging mainly between 5.5 and $7.5 \mathrm{mg} \mathrm{g}^{-1}$ (Fig. 2F). As occurred with Fe, Ti concentrations showed strong millennial scale variability. Ti concentrations tended to decrease during warmer substages (i.e. 7a, 7c, 7e, 9a, 9c, 9e and 11c) indicated by light ${ }^{18} \mathrm{O}$ G. bulloides values.

\subsection{Phosphorus sequential extraction}

Fig. 3A-D shows the concentration of each extracted $\mathrm{P}$ component during two intervals: (1) from $306 \mathrm{ka}$ to $342 \mathrm{ka}$ (i.e. first interval), and (2) from $248 \mathrm{ka}$ to $277 \mathrm{ka}$ (i.e. second interval). During the first interval (306-342 ka), $\mathrm{P}_{\text {oxy }}$ concentrations (Fig. 3A) showed little glacial/interglacial variability, with average concentrations of $60 \mu \mathrm{g} \mathrm{g}^{-1}$ (SD: $9 \mu \mathrm{g} \mathrm{g}^{-1}$ ). $\mathrm{P}_{\text {aut }}$ (Fig. 3B) exhibited concentrations of about $310 \mu \mathrm{g} \mathrm{g}^{-1}$ (around $50 \%$ of total $\mathrm{P}$ extracted $\left(\mathrm{P}_{\text {ext }}\right)$ ) during the glacial decreasing to about $150 \mu \mathrm{g} \mathrm{g}^{-1}$ at the interglacial. During Termination IV, a high $\mathrm{P}_{\text {aut }}$ concentration event $\left(680 \mu \mathrm{g} \mathrm{g}^{-1}, 73 \%\right.$ of total $\left.\mathrm{P}_{\mathrm{ext}}\right)$ centered at $335 \mathrm{ka}$ was recorded. While, $\mathrm{P}_{\mathrm{det}}$ concentrations (Fig. 3C) increased from values of about $90 \mathrm{\mu g} \mathrm{g}^{-1}$ (around $20 \%$ of total $\mathrm{P}_{\text {ext }}$ ) during the glacial to 

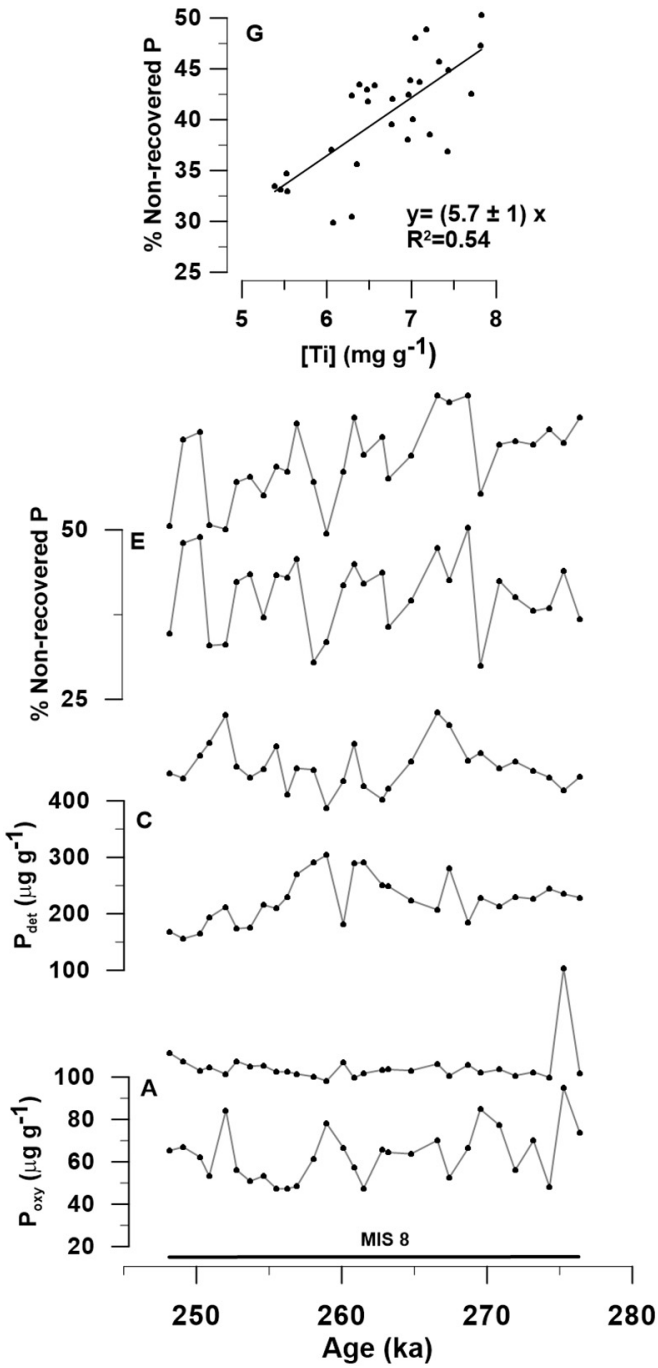
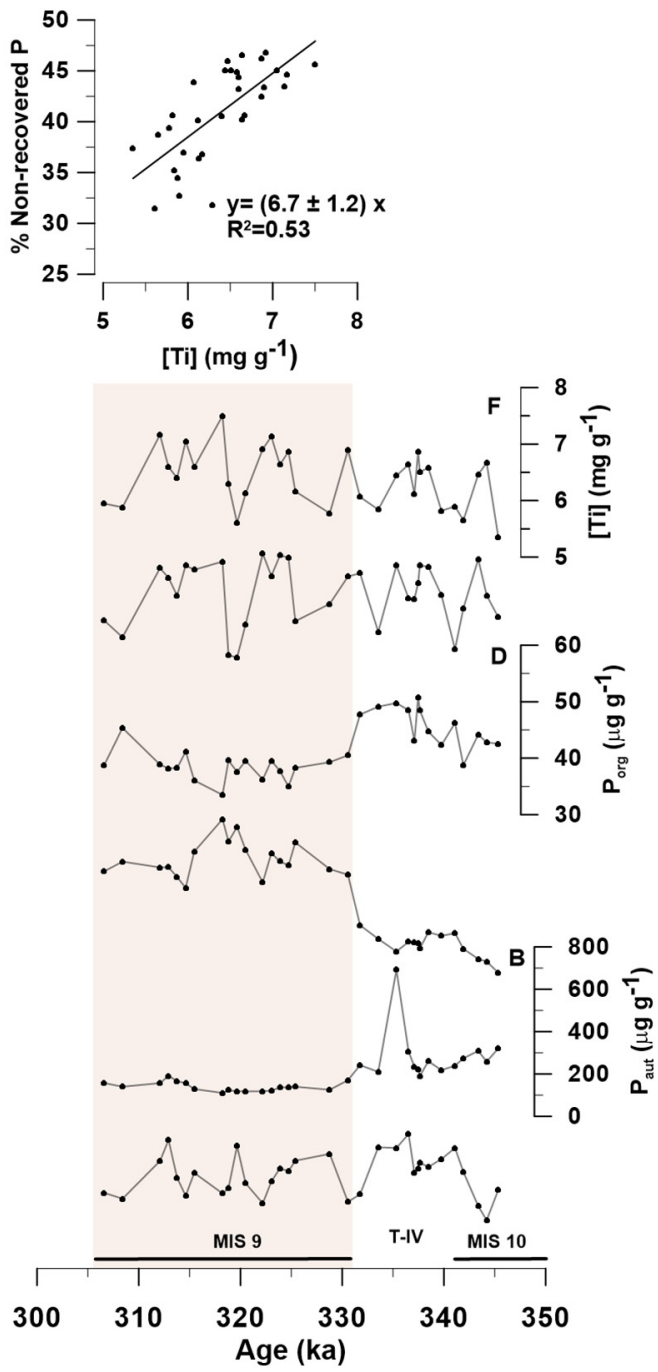

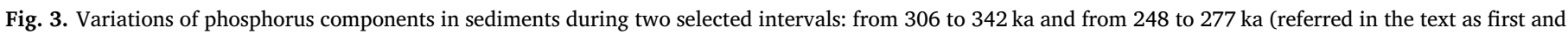

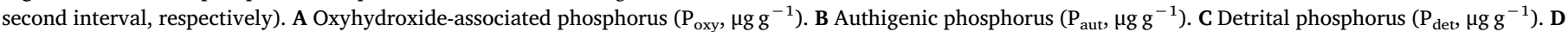

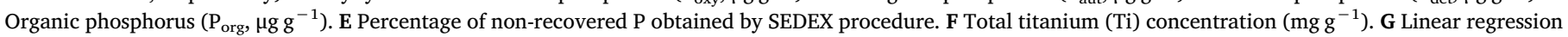
between $\%$ non-recovered $\mathrm{P}$ and total titanium concentration $\left(\mathrm{mg} \mathrm{g}^{-1}\right)$, regression slope and determination coefficient are also displayed.

about $270 \mu \mathrm{gg}^{-1}$ (around $60 \%$ of total $\mathrm{P}_{\mathrm{ext}}$ ) at the interglacial. $\mathrm{P}_{\text {org }}$ concentrations (Fig. 3D) followed the same trend as $P_{\text {aut }}$ with less pronounced changes, except for the high $\mathrm{P}_{\text {aut }}$ deposition event. $\mathrm{P}_{\text {org }}$ ranged from $60 \mathrm{\mu g} \mathrm{g}^{-1}$ (around $9 \%$ of total $\mathrm{P}_{\text {ext }}$ ) during MIS 10 to $30 \mathrm{\mu g} \mathrm{g}^{-1}$ (around $7 \%$ of total $\mathrm{P}_{\mathrm{ext}}$ ) at times of MIS 9 .

During the second interval $(248-277 \mathrm{ka}), \mathrm{P}_{\text {oxy }}$ concentrations (Fig. 3A) oscillated around an average of $60 \mu \mathrm{g} \mathrm{g}^{-1}$ (SD: $12 \mu \mathrm{g} \mathrm{g}^{-1}$ ). $\mathrm{P}_{\text {aut }}$ (Fig. 3B) concentrations were about $180 \mu \mathrm{gg}^{-1}$ (around $35 \%$ of the total $\left.\mathrm{P}_{\mathrm{ext}}\right)$ at the beginning of the interval and slightly decreased to about $150 \mu \mathrm{g} \mathrm{g}^{-1}$ around $260 \mathrm{ka}$. After this point, values increased to about $270 \mu \mathrm{g} \mathrm{g}^{-1}$ (around $50 \%$ of the total $\mathrm{P}_{\text {ext }}$ ) at the end of glacial stage MIS 8. A high authigenic concentration event $\left(680 \mu \mathrm{g} \mathrm{g}^{-1}, 65 \%\right.$ of the total $\mathrm{P}_{\text {ext }}$ ) occurred around $275 \mathrm{ka}$. $\mathrm{P}_{\mathrm{det}}$ concentrations (Fig. 3C) were $210 \mu \mathrm{g} \mathrm{g}^{-1}$ and represented about $40 \%$ of the total $\mathrm{P}_{\text {ext }}$ at the start of this interval, then increased to about $270 \mu \mathrm{g} \mathrm{g}^{-1}$ at $260 \mathrm{ka}(50 \%$ of total $\mathrm{P}_{\text {ext }}$ ). After that time, detrital $\mathrm{P}$ concentrations tended to decrease, reaching values of about $150 \mu \mathrm{g} \mathrm{g}^{-1}$ (around $30 \%$ of total $\mathrm{P}_{\mathrm{ext}}$ ) at the end of MIS 8. $\mathrm{P}_{\text {org }}$ concentrations (Fig. 3D) ranged from $60 \mu \mathrm{gg}^{-1}$ to $30 \mu \mathrm{g} \mathrm{g}^{-1}$ and mirrored $\mathrm{P}_{\mathrm{det}}$ concentrations from $277 \mathrm{ka}$ to $255 \mathrm{ka}$. After that, $\mathrm{P}_{\text {org }}$ concentration decreased together with $\mathrm{P}_{\text {det }}$ to the end of MIS 8.

By comparing P total measured by the ICP-OES with the sum of all components extracted by SEDEX technique, the proportion (in \%) of non-recovered P can be represented (Fig. 3E). It displays a strong millennial-scale behavior paralleling Ti concentrations (Fig. 3F) regardless of the environment where they were measured, i.e., predominant interglacial conditions for the first interval (306-342 ka), and glacial conditions for the second interval (248-277 ka). Correlation between \% non-recovered $\mathrm{P}$ and $\mathrm{Ti}$ concentrations for the first interval was: $\mathrm{r}_{1}=+0.72$, $\mathrm{p}$ (a) $<0.001, n=29$, while for the second interval was: $\mathrm{r}_{2}=+0.73$, $\mathrm{p}(\mathrm{a})<0.001, n=32$. Two linear regressions were constructed (Fig. 3G), indicating both regressions the same slope $\left(b_{1}=6.7 \pm 1.2, b_{2}=5.7 \pm 1\right)$ and non-significant intercept (p (a) $>0.05$ ).

\section{Discussion}

Phosphorus availability to primary producers is controlled by the balance between the input from rivers and the atmosphere, internal recycling and final removal through burial in sediments (Filippelli, 2008). Saharan dust is a great contributor of $P$ in some regions of the Mediterranean basin (Herut et al., 2005). This contribution, however, is negligible in our core site, situated at the upper slope of the Gulf of Lions, and under the influence of the Rhone input. This input has been highly variable in the past owing to sea-level oscillations (e.g., Sierro et al., 2009; Frigola et al., 2012), which, in theory, should have 
influenced P geochemistry. Moreover, during terminations, short millennial oscillations have been related with changes in the source of sediments arriving to the upper slope of the Gulf of Lions (Cortina et al., 2016). This millennial-scale variability, likely driven by atmospheric dynamics, could therefore influence P dynamics as well.

\subsection{Reliability of $P$ extraction}

Anoxic sediments are sensitive to chemical alterations when exposed to oxygen (Peterson et al., 1996), which usually occurs during core recovery and sample processing. In particular, oxidation of pyrite with oxygen produces sulfuric acid that can dissolve P-bearing Ca-minerals (Chi et al., 2006). This mechanism was suggested to cause an increase of $\mathrm{P}$ bound to reducible Fe and a decrease of Ca-bound $\mathrm{P}$ in anoxic sediments exposed to oxygen of the Baltic Sea (Lukkari et al., 2007) and Cape Verde Basin (Kraal et al., 2009).

Pyrite forms via the reaction of detrital iron minerals with $\mathrm{H}_{2} \mathrm{~S}$, that in turn is produced by the reductions of interstitial dissolved sulfate by bacteria using organic matter as a reducing agent and energy source (i.e. anoxic conditions) (Berner, 1984). Enrichments in Fe and S related with pyrite formation have been documented during and immediately below sapropel deposition in the Eastern Mediterranean (Passier et al., 1997, 1999). In our study, five distinctive periods of concurrent Fe and $S$ excursions were monitored (Fig. 2D, E). These periods are sensitive to pyrite oxidation which could affect $\mathrm{P}$ components distribution. Of special interest are the events situated at MIS 8 around 252 and $260 \mathrm{ka}$, in which $\mathrm{P}$ component extraction was performed. During these two events, $\mathrm{P}_{\text {oxy }}$ increased to $90 \mu \mathrm{g} \mathrm{g}^{-1}$, indicating that part of $\mathrm{P}_{\text {aut }}$ might be transferred to $\mathrm{P}$ bound to reducible Fe. The average of $\mathrm{P}_{\text {oxy }}$ during MIS 8 is $60 \mu \mathrm{g} \mathrm{g}^{-1}$ with $\mathrm{SD}=13 \mu \mathrm{g} \mathrm{g}^{-1}$, which implies that $\mathrm{P}_{\text {oxy }}$ increases are close to the range of 2 times SD. Furthermore, no sharp decreases in $\mathrm{P}_{\text {aut }}$ were assessed during these two events. Hence, we consider that core retrieving and sample processing did not affect significantly $\mathrm{P}$ results.

Between 50 and $25 \%$ of $P$ was not recovered by SEDEX technique, and this residual $\mathrm{P}$ is correlated with [Ti] in the two intervals studied with coefficients of determination above 0.5 (Fig. 3E, F, G). Moreover, weak correlations were found between previous published [Al] data (Cortina et al., 2013) and \% non-recovered $\mathrm{P}\left(\mathrm{R}^{2}<0.2\right)$. Titanium is preferentially concentrated in the coarser sediment fractions (Spears and Kanaris-Sotiriou, 1976) being an indicator of average grain size. Hence, our data suggest that an important fraction of $\mathrm{P}$ deposited in the Gulf of Lions is associated with coarser sediments which enters and exits the marine system with little or no geochemical interaction with seawater and so can be defined as non-reactive P, similar to the operationally defined $P_{\text {det }}$ (März et al., 2014). Considering that all non-extracted $\mathrm{P}$ is associated to detrital fraction, a correction of $\mathrm{P}_{\mathrm{det}}$ can be calculated:

$\% \mathrm{P}_{\text {detcor }}=\left(\left(\mathrm{P}_{\text {det }}+\mathrm{P}_{\text {non-extracted }}\right) / \mathrm{P}_{\text {totalICP }}\right) \times 100$

In both intervals (Figs. $4 \mathrm{~A}, 5 \mathrm{C}$ ), the $\% \mathrm{P}_{\text {det_cor }}$ parallels the $\% \mathrm{P}_{\mathrm{det}}$ behavior, suggesting that the limitations of the SEDEX technique do not have a strong effect on our interpretations.

\subsection{Sea-level change impacts on $P$ burial}

Glacial/interglacial sea-level change has a strong effect on sediments deposited on the upper slope of the Gulf of Lions (e.g., Sierro et al., 2009; Frigola et al., 2012; Cortina et al., 2011). Sedimentation rates values ranged from below $0.2 \mathrm{~m} * \mathrm{kyr}^{-1}$ during interglacial stages until values above $1 \mathrm{~m} * \mathrm{kyr}^{-1}$ during glacials (Fig. 2B). These data suggest that higher $\mathrm{P}$ fluxes were associated to glacial stages with high sedimentation rates as a consequence of sea level fall that led to seaward migration of the Rhone's mouth. In contrast, during interglacial stages sea level rose and the mouth of the Rhone migrated landward, decreasing the amount of sediments that carried for the Rhone reached the upper slope and consequently the P flux. Interestingly, no glacial/ interglacial total $\mathrm{P}$ concentration variability was recorded (Fig. 2C) which appears counterintuitive given such strong sedimentation rate differences and the ensuing significant increase on $\mathrm{P}$ fluxes. In fact, similar results were achieved in a study that compared some broadly distributed open ocean versus continental margins locations (Filippelli, 1997).

The study of the different geochemical fractions of $P$ therefore offers crucial information for understanding P biogeochemistry in two completely depositional scenarios: (1) glacial with PRGL1 under environmental conditions typical of continental margin locations and (2) interglacial, with PRGL1 less influenced by continental margin processes.

The influence of glacial/interglacial sea-level changes in the geochemical character of $\mathrm{P}$ accumulated in the upper slope is seen in Fig. 4. The first interval (MIS 9-10) reveals an increasing trend of $\% \mathrm{P}_{\text {det }}$ (Fig. 4A) from MIS 10 to MIS 9. These results highlight the strong effect that sedimentation rate has on $\mathrm{P}$ biogeochemistry. The fact that $\% \mathrm{P}_{\mathrm{det}}$ increased during MIS 9 is likely the result of the remineralization of $\mathrm{P}_{\text {react }}$ during highstands. At these times, sediment rate slowed and reactive P-bearing components remained longer in the reactive upper sediment, undergoing winnowing by bottom currents during thousands of years (Sierro et al., 1999, 2009). This resulted in an increased dissolution of $\mathrm{P}_{\text {react }}$ and enhanced recycling of dissolved $\mathrm{P}$ into the overlying water column. In contrast, higher sedimentation rate during glacial stages resulted in more rapid burial, effectively removing $P_{\text {react }}$ from the early diagenetic zone and allowing for greater preservation. This mechanism is supported by the glacial/interglacial differences in the $\mathrm{C}_{\text {org }}: \mathrm{N}$ (Fig. 4E), which usually varies in response to changes of the dominant source of organic matter from marine (low values) to terrestrial (high values) (Meyers, 1994). The fact that $\mathrm{C}_{\text {org }}: \mathrm{N}$ ratio was higher during interglacial stages was attributed to a reduced sediment input that resulted in extended periods of organic matter degradation at the sediment water interface favoring the preservation of more refractory organic matter (Cortina et al., 2013). As a result, the overall efficiency of $\mathrm{P}$ burial will decrease during highstands as indicated by the increase of the $C_{\text {org }}: P_{\text {react }}$ (Fig. 4D).

\subsection{Periods of distinctive $P$ deposition and their implications for Western Mediterranean environmental conditions}

Two significant events of $\mathrm{P}$ burial associated with the authigenic phase were recorded (Fig. 3B), taking place during Termination IV $\left(\mathrm{P}_{\text {aut } 1}\right)$ and around $275 \mathrm{ka}\left(\mathrm{P}_{\mathrm{aut} 2}\right)$. They are associated to the two strongest ice-rafted debris (IRD) deposition recorded in the North Atlantic for the last $500 \mathrm{kyr}$ (McManus et al., 1999). During the last glacial, it has been postulated that major IRD layers resulted from catastrophic iceberg calving along the ice sheet margins of North Atlantic (Broecker et al., 1992), which coincided with the coldest events in the North Atlantic, referred as Heinrich Events (HE). In the Western Mediterranean, the appearance of the polar specie Neogloboquadrina pachyderma (s) has been tightly linked to such North Atlantic HE (Sierro et al., 2005, 2009; Cortina et al., 2013). At the Gulf of Lions, cold conditions reached during HE has been linked to enhancement of northwesterly winds, water column mixing and bottom turbulence that promoted the appearance of the benthic foraminifer species Trifarina angulosa (Cortina et al., 2013).

\subsection{1. $P_{\text {aut } 1}$ at Termination IV}

The $\mathrm{P}_{\text {aut } 1}$ event during Termination IV (Fig. 4B) is characterized by high IRD discharge in the North Atlantic (McManus et al., 1999) and the appearance of cold planktic foraminifer species $N$. pachyderma (s) in the Gulf of Lions (Fig. 4H) (Cortina et al., 2013). During this period, organic rich layer (ORL) deposition took place in the Alboran Sea (Western Mediterranean) (unpublished data). In fact, sediment cores from Alboran Sea reported increases in total organic carbon (TOC) during this period (Murat, 1999). Owing to the recurrent oxygenation of the bottom driven by northwesterly winds, ORL deposition is not 


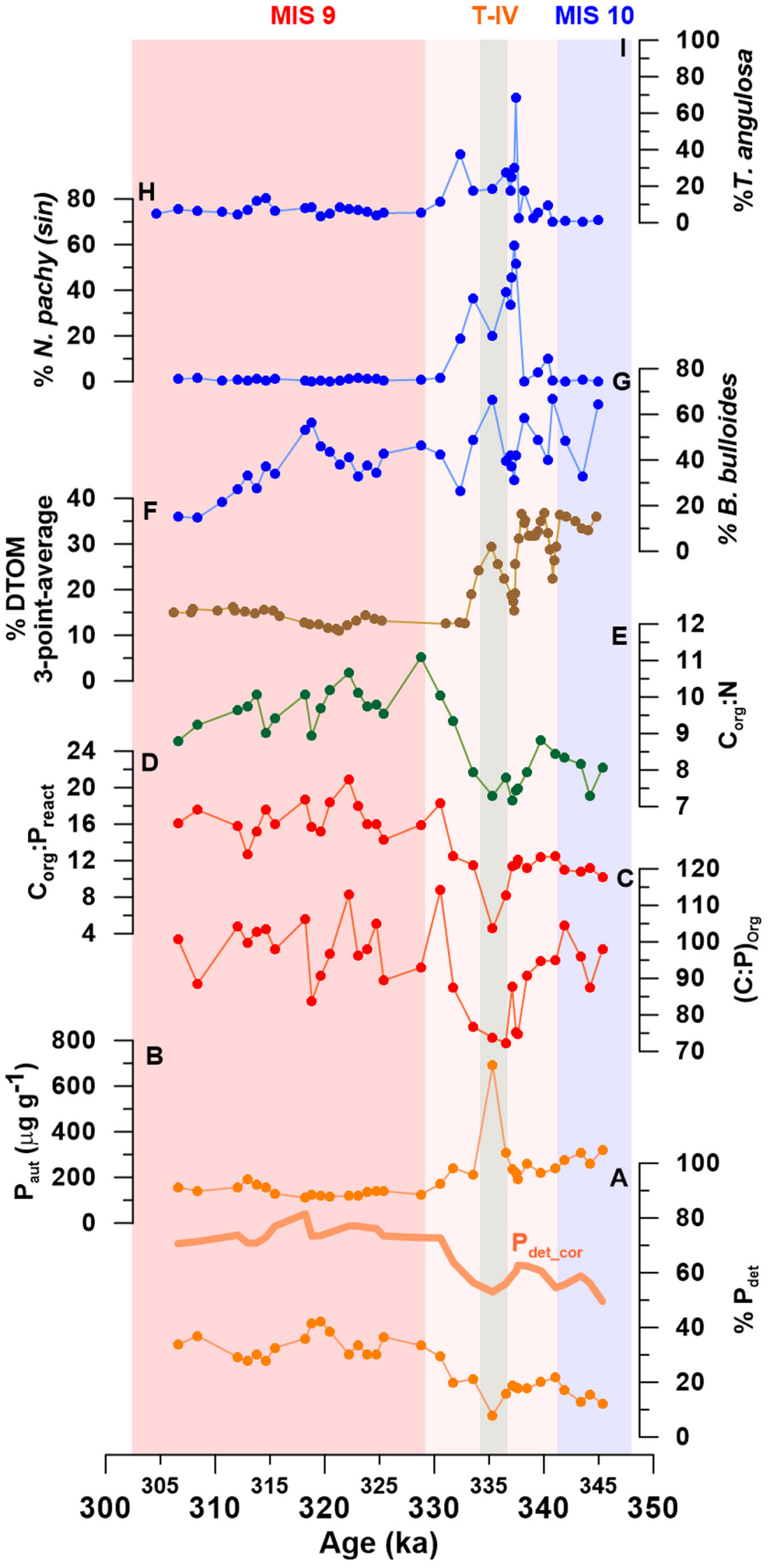

Fig. 4. Effects of sea-level changes and flooding events in phosphorus deposited in the upper slope of the Gulf of Lions from 306 to $342 \mathrm{ka}$. A \% Detrital phosphorus (\% $\mathrm{P}_{\mathrm{det}}$ ) calculated as the relative amount of $\mathrm{P}_{\mathrm{det}}$ extracted by SEDEX procedure in the total $\mathrm{P}$ concentration measured by ICP-EOS. Thicker and continuous line depicts $\% \mathrm{P}_{\text {det_cor }}$ that assumes all non-extracted $\mathrm{P}$ has a detrital origin. $\mathrm{B}$ Authigenic phosphorus $\left(\mathrm{P}_{\text {aut }}, \mu \mathrm{g} \mathrm{g}^{-1}\right)$. C $(\mathrm{C}: \mathrm{P})_{\text {org }}$ ratio. $\mathbf{D} \mathrm{C}_{\text {org }}: \mathrm{P}_{\text {react }}$ ratio. $\mathbf{E}$ Weight $\mathrm{C}_{\text {org }}: \mathrm{N}$ ratio (Cortina et al., 2013). F Three-point-average percentage of degraded terrestrial organic matter (\% DTOM) (Cortina et al., 2016). G \% Globigerina bulloides (Cortina et al., 2013). H \% Neogloboquadrina pachyderma (sin) (Cortina et al., 2013). I \% Trifarina angulosa (Cortina et al., 2013). Red band represents MIS 9. Blue band represents MIS 10. Orange band represents Termination IV. Green band represents authigenic phosphorus high-deposition event $\left(\mathrm{P}_{\text {aut1 }}\right)$. (For interpretation of the references to color in this figure legend, the reader is referred to the web version of this article.) 


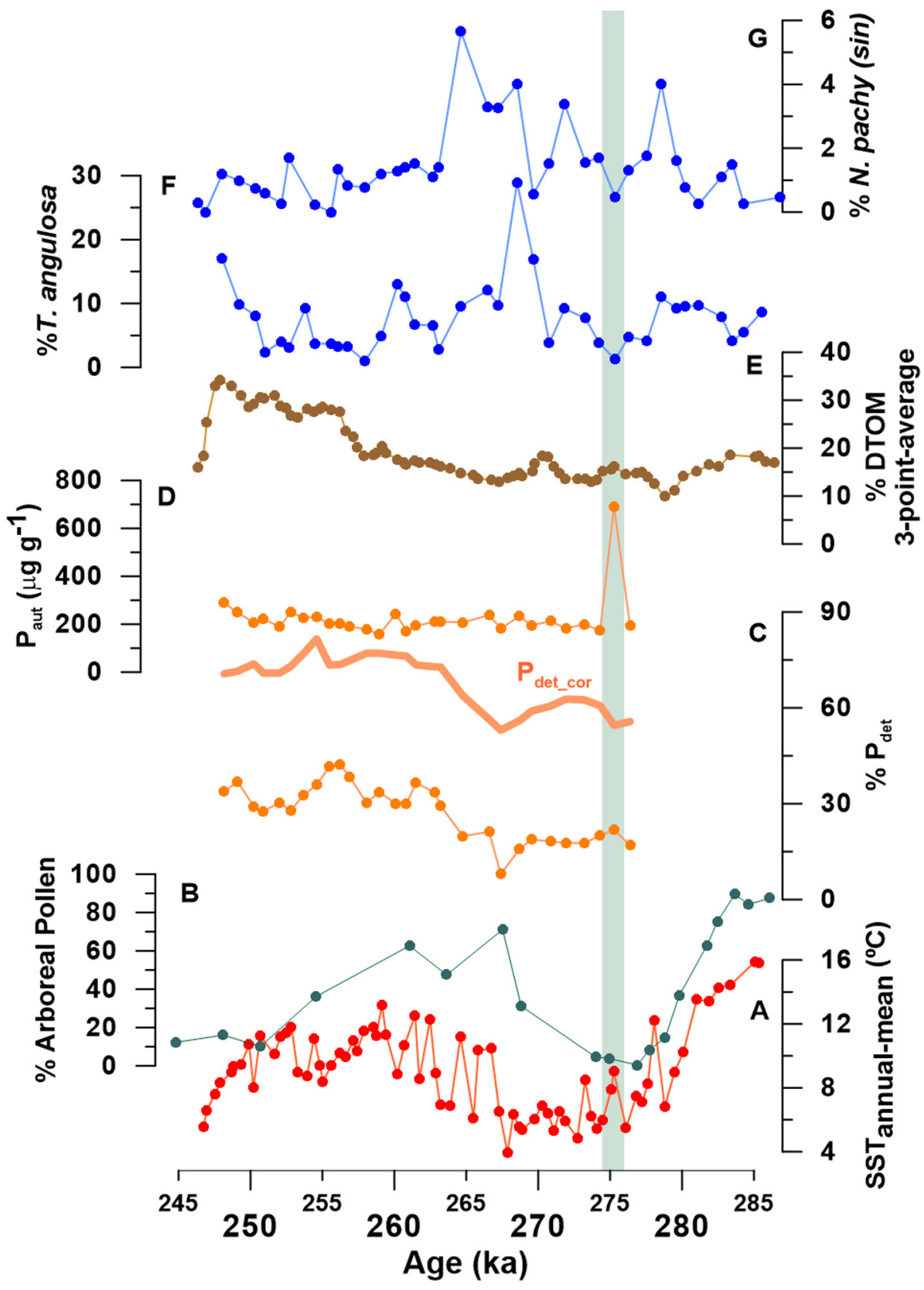

Fig. 5. Effects of sea-level changes and flooding events in phosphorus deposited in the upper slope of the Gulf of Lions from 248 to 277 ka. A Sea Surface Temperature (SST) (Cortina et al., 2015). B Percentage of Arboreal Pollen (Tzedakis et al., 2003). C \% Detrital phosphorus $\left(\% \mathrm{P}_{\mathrm{det}}\right)$ calculated as the relative amount of $\mathrm{P}_{\text {det }}$ extracted by SEDEX procedure in the total P concentration measured by ICP-EOS. Thicker and continuous line depicts $\% \mathrm{P}_{\text {det_cor }}$ that assumes all non-extracted $\mathbf{P}$ has a detrital origin. D

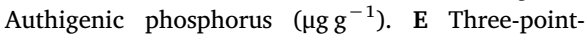
average percentage of degraded terrestrial organic matter (\% DTOM) (Cortina et al., 2016). F \% Trifarina angulosa (Cortina et al., 2013). G \% Neogloboquadrina pachyderma (sin) (Cortina et al., 2013). Green band represents authigenic phosphorus highdeposition event $\left(\mathrm{P}_{\mathrm{aut} 2}\right)$. (For interpretation of the references to color in this figure legend, the reader is referred to the web version of this article.) expected in the Gulf of Lions. Nonetheless, it is a key area regarding primary productivity in the rather oligotrophic Mediterranean Sea (Lefèvre et al., 1997) and P plays an important role on the growth of primary producers. Therefore, effects on $\mathrm{P}$ cycling of a mechanism influencing the whole Western Mediterranean may potentially be monitored.

During this period, strong glacial/interglacial changes in the sedimentation rate are expected. These nonsteady-state processes have been demonstrated to have a high potential for producing and preserving authigenic minerals (Kasten et al., 1998; Thomson et al., 1984). Therefore, high $\mathrm{P}_{\text {aut }}$ deposition events could be interpreted as the result of nonsteady-state diagenetic processes rather than changes in the environment conditions. However, no enrichment of Fe sulfides (Fe and S) (Kasten et al., 1998) typical of nonsteady-state diagenetic processes are monitored during Termination IV (Fig. 2D, E), suggesting an environmental control only of $\mathrm{P}_{\text {aut1 }}$ formation.

Based on the proportion of fresh versus degraded terrestrial organic matter (DTOM), and analogous to last glacial, rapid cold/warm oscillations were identified during Termination IV in the Gulf of Lions (Cortina et al., 2016). These rapid cold/warm oscillations detected in the Western Mediterranean basin, responded most probably to a collapse/resumption of the Atlantic meridional overturning circulation (AMOC). During a collapse (Broecker, 1994), increased atmospheric gradient in the North Atlantic induced dry and cold conditions in the Western Mediterranean region (e.g. Cacho et al., 1999; Sánchez Goñi et al., 2002). These conditions, reduced runoff (Jiménez-Espejo et al., 2007; Rodrigo-Gámiz et al., 2011) and decreased the proportion of DTOM (Fig. 4F). However, the AMOC resumption produced a decrease in the atmospheric gradient in the North Atlantic, which resulted in warmer and more humid conditions in the Western Mediterranean. Such conditions led to increased continental runoff and the ensuing erosion of old and reworked material form the Rhone catchment area incrementing \% DTOM.

The high $\mathrm{P}_{\text {aut1 }}$ deposition event (Fig. 4B) and the ensuing enhancement of P burial efficiency (Fig. 4D) was contemporaneous with the increased continental runoff episode characterized by an increase in 
primary productivity in the water column as indicated by the rise in the productive planktic foraminifer species G. bulloides (Bárcena et al., 2004) (Fig. 4G) and the low $\mathrm{C}_{\text {org }}: \mathrm{N}$ values (Fig. 4E). An external source of Ca-P minerals (Eijsink et al., 2000; Kraal et al., 2012) is discarded because the highest input of material carried by the Rhone at PRGL occurred during glacial maxima (Cortina et al., 2016), and no increases of $\mathrm{P}_{\text {aut }}$ were detected during those times. Therefore, two mechanisms can be invoked to explain $\mathrm{P}_{\text {aut } 1}$ deposition: (1) the precipitation of $\mathrm{P}$ released by organic matter as carbonate fluoropatite (CFA) (Filippelli, 2001), and (2) enhanced burial of biogenic $\mathrm{Ca}-\mathrm{P}$ (i.e. fish debris) (Schenau and De Lange, 2001; Slomp et al., 2002; Schenau et al., 2005).

During Termination IV, paleoredox/sedimentation rate variability marked by (C:P) org (Fig. 4C) seems to mirror \% DTOM, however, its lower resolution with regard the alkane-based proxy challenges their direct comparison. Nonetheless, the lowest $(\mathrm{C}: \mathrm{P})_{\text {org }}$ values were achieved during the increased continental runoff episode. Weakened bottom turbulence compared with pre and post continental runoff episodes is displayed by T. angulosa (Fig. 4I) which indicates lower oxygenation conditions during this episode. Hence, increase of $\mathrm{P}_{\text {org }}$ with respect $\mathrm{C}$ is not linked to paleoredox control. On the other hand, elevated values of both fresh organic matter (low $\mathrm{C}_{\text {org }}: \mathrm{N}$ ) and primary productivity (high $\% G$. bulloides) are synchronous with the increment of $\%$ DTOM. These results suggest that enhancement of primary productivity driven by increased nutrients from river runoff overcame the signal of detrital organic matter (high \% DTOM). Increased sedimentation rate owing to flooding events could favor low (C:P) $)_{\text {org }}$ in sediments, however, by itself cannot explain lower (C:P) org reached during Termination IV compared with glacial maximum, since this would imply higher sedimentation rate when sea level is increasing. For this reason, high supply of fresh organic matter with low (C:P) ${ }_{\text {org values }}$ (Ruttenberg and Goñi, 1997) via primary productivity is essential to driving low (C:P) $)_{\text {org }}$ in sediments. Increased primary productivity would lead to more abundant fish populations in the oxic part of the water column and higher rate of fish debris deposition (Suess, 1981; De Vries and Pearcy, 1982). Owing to its labile nature, P can experience rapid dissolution and contribute to porewater $\mathrm{PO}_{4}{ }^{3-}$ accumulation and subsequent authigenic $\mathrm{Ca}-\mathrm{P}$ formation (Babu and Nath, 2005). Furthermore, high sedimentation rate derived from both increased runoff and productivity could promote $\mathrm{P}$ biogenic preservation as demonstrated in other areas (Sirocko and Lange, 1991; Thamban et al., 2001; Slomp et al., 2002, 2004; Babu and Nath, 2005). Thus, the $\mathrm{P}_{\text {aut1 }}$ deposition event monitored during Termination IV most likely reflects a highproductivity event.

Radiocarbon dating has allowed a precise timing of events during the last ORL deposition (ORL1). During the Bolling-Allerod (B-A) in the Alboran Sea, several studies have pointed out humid conditions, increase of river discharge and stratification of the water column (Bárcena et al., 2001; Frigola et al., 2008; Fletcher et al., 2010; RodrigoGámiz et al., 2011), which led to increased marine productivity (Jimenez-Espejo et al., 2008) and low oxygen content in deep waters (Rogerson et al., 2008). Although the PRGL1 is located in shallow waters from the continental slope, the environmental conditions described for the ORL1 during B-A in the Alboran Sea resemble those that occurred during the $\mathrm{P}_{\text {aut } 1}$ deposition event. These results suggest that, akin to Termination I, during Termination IV enhanced marine productivity is restricted to a warm/flood event of ORL deposition. These results could be indicative of a secondary control of primary productivity in ORL deposition, i.e. stagnation, as the main driver (Rogerson et al., 2008)

\subsubsection{The $P_{\text {aut } 2}$ event $(275 \mathrm{ka})$}

The $\mathrm{P}_{\text {aut2 }}$ event (Fig. 5D) occurs during strong IRD deposition in the North Atlantic as well as the $\mathrm{P}_{\text {aut1 }}$, but no ORL was deposited in the Alboran Sea at this time (Murat, 1999). Cold conditions were reached in the Mediterranean as recorded by SST (Fig. 5A) and AP (Fig. 5B). Similar to Termination IV, though with smaller ranges, $N$. pachyderma
(0-6\%) (Fig. 5G) and T. angulosa (0-25\%) (Fig. 5F) oscillate between colder/high bottom turbulence and warmer/low bottom turbulence. Such low variability could be the result of a higher sea level during this interval ( $\approx 30 \mathrm{~m}$ according to Waelbroeck et al., 2002), in agreement with low \%DTOM values (Fig. 5E). Short millennial-scale events are recorded, indicating warmer (high SST, low N. pachyderma (sin)) and decreased bottom turbulence (lower \% T. angulosa), coinciding with the $\mathrm{P}_{\text {aut2. }}$. Marine productivity could be also considered high given that assemblages are dominated by $G$. bulloides (34.5\%) and $N$ pachyderma (dex) (26.5\%) (Cortina et al., 2013). The emergence of $N$. pachyderma (dex) could be the result of higher sea level and the development of a thermocline and a Deep Chlorophyll Maximum (DCP) (Pujol and Grazzini, 1995), which were not present during the lowstand at $P_{\text {aut1 }}$.

Therefore, $\mathrm{P}_{\text {aut1 }}$ and $\mathrm{P}_{\text {aut2}}$ seem to be caused by productivity events associated with warmer episodes during strong IRD discharge in the North Atlantic. The fact that $\mathrm{P}_{\text {aut }}$ deposition depended on atmospheric dynamics reflects the strong sensitivity that the Mediterranean Sea had to global climate processes.

\section{Conclusions}

During glacial (MIS 10) and interglacial (MIS 9) intervals the deposition of $\mathrm{P}$ in the upper slope of the Gulf of Lions was strongly influenced by sedimentation rates, which in turn was driven by sea-level changes. During higher sea level (i.e. warmer stages), the increase in the accommodation space in the continental shelf decreased the amount of sediments reaching the upper slope of the Gulf of Lions, thus reducing the sedimentation rate and increasing $\mathrm{P}_{\text {react }}$ time in the geochemically active sediment-water interface. This enhanced recycling and decreased the efficiency of P burial. During lower sea levels (i.e. colder stages), the increase in sedimentation rate as a consequence of decreased accommodation space reduced $\mathrm{P}_{\text {react }}$ time at the sedimentwater interface, enhancing $P$ burial efficiency. These results indicate the importance of continental margins in P burial efficiency at glacial/interglacial timescales. Besides this general glacial/interglacial trend, two highly-efficient $\mathrm{P}$ deposition events were identified from MIS 6 to MIS 11. These events occurred during periods with rapid cold/warm transitions associated with ice rafting and meltwater events in the North Atlantic, such as Termination IV and IRD deposition event centered around $275 \mathrm{ka}$. Specifically, $\mathrm{P}_{\text {aut }}$ excursions occurred during short warm periods. We hypothesize that enhanced continental runoff associated with warm and humid periods increased nutrients in the mixed layer, stimulating primary productivity that led to more abundant fish populations and higher rate of fish debris deposition. Due to its labile nature, rapid dissolution is expected, contributing to porewater $\mathrm{PO}_{4}{ }^{3-}$ accumulation and ensuing $\mathrm{Ca}-\mathrm{P}$ formation. Our results highlight that both sedimentation rates driven by sea-level and ice-sheets oscillations that influenced atmospheric dynamics at global scale have strong impact on P burial from millennial to larger climatic cycles. These processes could influence P remineralization from sediments and consequently primary productivity events on the northwestern Mediterranean at different timescales.

\section{Acknowledgments}

Two anonymous reviewers are greatly acknowledged for their comments, which improved the final version of this manuscript. This work was funded by the Spanish "Ministerio de Ciencia e Innovación" MICINN trough the projects CGL2011-26493, GRACCIE (CONSOLIDERINGENIO CSD 2007-00067) and "Herramientas web y redes sociales de carácter profesional y científico en la red consolider" GRACCIE (CTM2014-59111-REDC), the regional government of Castilla y León project GR34, and by the MEC FPI Grant (BES-2007-17602) (A.C.) 


\section{Appendix A. Supplementary data}

Supplementary data to this article can be found online at https:// doi.org/10.1016/j.palaeo.2018.03.010.

\section{References}

Algeo, T.J., Ingall, E., 2007. Sedimentary C org: P ratios, paleocean ventilation, and Phanerozoic atmospheric pO 2. Palaeogeogr. Palaeoclimatol. Palaeoecol. 256, 130-155.

Anderson, L.D., Delaney, M.L., Faul, K.L., 2001. Carbon to phosphorus ratios in sediments: implications for nutrient cycling. Glob. Biogeochem. Cycles 15, 65-79.

Babu, C.P., Nath, B.N., 2005. Processes controlling forms of phosphorus in surficial sediments from the eastern Arabian Sea impinged by varying bottom water oxygenation conditions. Deep-Sea Res. II Top. Stud. Oceanogr. 52, 1965-1980.

Bárcena, M.A., Cacho, I., Abrantes, F., Sierro, F.J., Grimalt, J.O., Flores, J.A., 2001. Paleoproductivity variations related to climatic conditions in the Alboran Sea (western Mediterranean) during the last glacial-interglacial transition: the diatom record. Palaeogeogr. Palaeoclimatol. Palaeoecol. 167, 337-357.

Bárcena, M.A., Flores, J.A., Sierro, F.J., Perez-Folgado, M., Fabres, J., Calafat, A., Canals, M., 2004. Planktonic response to main oceanographic changes in the Alboran Sea (Western Mediterranean) as documented in sediment traps and surface sediments. Mar. Micropaleontol. 53, 423-445.

Bassetti, M.A., Jouet, G., Dufois, F., Berné, S., Rabineau, M., Taviani, M., 2006. Sand bodies at the shelf edge in the Gulf of Lions (Western Mediterranean): deglacial history and modern processes. Mar. Geol. 234, 93-109.

Berne, S., Jouet, G., Bassetti, M.A., Dennielou, B., Taviani, M., 2007. Late Glacial to Preboreal sea-level rise recorded by the Rhone deltaic system (NW Mediterranean). Mar. Geol. 245, 65-88.

Berner, R.A., 1973. Phosphate removal from sea water by adsorption on volcanogenic ferric oxides. Earth Planet. Sci. Lett. 18, 77-86.

Berner, R.A., 1984. Sedimentary pyrite formation: an update. Geochim. Cosmochim. Acta 48, 605-615.

Béthoux, J.P., 1979. Budgets of the Mediterranean Sea - their dependence on the local climate and on the characteristics of the Atlantic waters. Oceanol. Acta 2, 157-163.

Broecker, W.S., 1994. Massive iceberg discharges as triggers for global climate change. Nature 372, 421-424.

Broecker, W., Bond, G., Klas, M., Clark, E., McManus, J., 1992. Origin of the northern Atlantic's Heinrich events. Clim. Dyn. 6, 265-273.

Cacho, I., Grimalt, J.O., Pelejero, C., Canals, M., Sierro, F.J., Flores, J.A., Shackleton, N., 1999. Dansgaard-Oeschger and Heinrich event imprints in Alboran Sea paleotemperatures. Paleoceanography 14, 698-705.

Canals, M., Puig, P., De Madron, X.D., Heussner, S., Palanques, A., Fabres, J., 2006. Flushing submarine canyons. Nature 444, 354-357.

Chi, R., Xiao, C., Gao, H., 2006. Bioleaching of phosphorus from rock phosphate containing pyrites by Acidithiobacillus ferrooxidans. Miner. Eng. 19, 979-981.

Cortina, A., Sierro, F.J., González-Mora, B., Asioli, A., Flores, J.A., 2011. Impact of climate and sea level changes on the ventilation of intermediate water and benthic foraminifer assemblages in the Gulf of Lions, off South France, during MIS 6 and 7. Palaeogeogr. Palaeoclimatol. Palaeoecol. 309, 215-228.

Cortina, A., Sierro, F.J., Filippelli, G., Flores, J.A., Berné, S., 2013. Changes in planktic and benthic foraminifer assemblages in the Gulf of Lions, off south France: response to climate and sea level change from MIS 6 to MIS 11. Geochem. Geophys. Geosyst. $14,1258-1276$.

Cortina, A., Sierro, F.J., Flores, J.A., Martrat, B., Grimalt, J.O., 2015. The response of SST to insolation and ice sheet variability from MIS 3 to MIS 11 in the northwestern Mediterranean Sea (Gulf of Lions). Geophys. Res. Lett. 42, 10366-10374.

Cortina, A., Grimalt, J.O., Rigual-Hernández, A., Ballegeer, A.M., Martrat, B., Sierro, F.J., Flores, J.A., 2016. The impact of ice-sheet dynamics in western Mediterranean environmental conditions during Terminations. An approach based on terrestrial long chain n-alkanes deposited in the upper slope of the Gulf of Lions. Chem. Geol. 430, 21-33.

De Vries, T.J., Pearcy, W.G., 1982. Fish debris in sediments of the upwelling zone off central Peru: a late Quaternary record. Deep Sea Res. Part A 29, 8797-95109.

Eijsink, L.M., Krom, M.D., Herut, B., 2000. Speciation and burial flux of phosphorus in the surface sediments of the eastern Mediterranean. Am. J. Sci. 300, 483-503.

Filippelli, G.M., 1997. Controls on phosphorus concentration and accumulation in oceanic sediments. Mar. Geol. 139, 231-240. http://dx.doi.org/10.1016/S0025-3227(96) 00113-2.

Filippelli, G.M., 2001. Carbon and phosphorus cycling in anoxic sediments of the Saanich Inlet, British Columbia. Mar. Geol. 174, 307-321.

Filippelli, G.M., 2008. The global phosphorus cycle: past, present, and future. Elements 4, 89-95.

Filippelli, G.M., Delaney, M.L., 1995. Phosphorus geochemistry and accumulation rates in the eastern equatorial pacific ocean: results from leg $138^{1}$. In: Pisias, N.G., Mayer, L.A., Janecek, T.R., Palmer-Julson, A., van Andel, T.H. (Eds.), Proceedings of the Ocean Drilling Program, Scientific Results, pp. 757-767.

Filippelli, G.M., Delaney, M.L., 1996. Phosphorus geochemistry of equatorial Pacific sediments. Geochim. Cosmochim. Acta 60, 1479-1495.

Fletcher, W.J., Goni, M.F.S., Allen, J.R.M., Cheddadi, R., Combourieu-Nebout, N., Huntley, B., Lawson, I., Londeix, L., Magri, D., Margari, V., 2010. Millennial-scale variability during the last glacial in vegetation records from Europe. Quat. Sci. Rev. $29,2839-2864$

Frigola, J., Moreno, A., Cacho, I., Canals, M., Sierro, F.J., Flores, J.A., Grimalt, J.O., 2008.
Evidence of abrupt changes in Western Mediterranean Deep Water circulation during the last 50 kyr: a high-resolution marine record from the Balearic Sea. Quat. Int. 181, 88-104.

Frigola, J., Canals, M., Cacho, I., Moreno, A., Sierro, F.J., Flores, J.A., Berné, S., Jouet, G., Dennielou, B., Herrera, G., Pasqual, C., Grimalt, J.O., Galavazi, M., Schneider, R., 2012. A $500 \mathrm{kyr}$ record of global sea-level oscillations in the Gulf of Lion, Mediterranean Sea: new insights into MIS 3 sea-level variability. Clim. Past 8, 1067-1077.

Froelich, P.N., Arthur, M.A., Burnett, W.C., Deakin, M., Hensley, V., Jahnke, R., Kaul, L., Kim, K.-H., Roe, K., Soutar, A., 1988. Early diagenesis of organic matter in Peru continental margin sediments: phosphorite precipitation. Mar. Geol. 80, 309-343.

Herut, B., Zohary, T., Krom, M.D., Mantoura, R.F.C., Pitta, P., Psarra, S., Rassoulzadegan, F., Tanaka, T., Thingstad, T.F., 2005. Response of East Mediterranean surface water to Saharan dust: on-board microcosm experiment and field observations. Deep-Sea Res. II Top. Stud. Oceanogr. 52, 3024-3040.

Jiménez-Espejo, F.J., Martínez-Ruiz, F., Finlayson, C., Paytan, A., Sakamoto, T., OrtegaHuertas, M., Finlayson, G., Iijima, K., Gallego-Torres, D., Fa, D., 2007. Climate forcing and Neanderthal extinction in Southern Iberia: insights from a multiproxy marine record. Quat. Sci. Rev. 26, 836-852.

Jimenez-Espejo, F.J., Martinez-Ruiz, F., Rogerson, M., González-Donoso, J.M., Romero, O.E., Linares, D., Sakamoto, T., Gallego-Torres, D., Rueda Ruiz, J.L., Ortega-Huertas, M., Perez Claros, J.A., 2008. Detrital input, productivity fluctuations, and water mass circulation in the westernmost Mediterranean Sea since the Last Glacial Maximum. Geochem. Geophys. Geosyst. 9 (11), Q11U02.

Jouet, G., Berné, S., Rabineau, M., Bassetti, M.A., Bernier, P., Dennielou, B., Sierro, F.J., Flores, J.A., Taviani, M., 2006. Shoreface migrations at the shelf edge and sea-level changes around the Last Glacial Maximum (Gulf of Lions, NW Mediterranean). Mar. Geol. 234, 21-42.

Kasten, S., Freudenthal, T., Gingele, F.X., Schulz, H.D., 1998. Simultaneous formation of iron-rich layers at different redox boundaries in sediments of the Amazon deep-sea fan. Geochim. Cosmochim. Acta 62, 2253-2264.

Kerrn-Jespersen, J.P., Henze, M., 1993. Biological phosphorus uptake under anoxic and aerobic conditions. Water Res. 27, 617-624.

Kraal, P., Slomp, C.P., Forster, A., Kuypers, M.M.M., Sluijs, A., 2009. Pyrite oxidation during sample storage determines phosphorus fractionation in carbonate-poor anoxic sediments. Geochim. Cosmochim. Acta 73, 3277-3290.

Kraal, P., Slomp, C.P., Reed, D.C., Reichart, G.-J., Poulton, S.W., 2012. Sedimentary phosphorus and iron cycling in and below the oxygen minimum zone of the northern Arabian Sea. Biogeosciences 9, 2603-2624.

Krom, M.D., Kress, N., Brenner, S., Gordon, L.I., 1991. Phosphorus limitation of primary productivity in the eastern Mediterranean Sea. Limnol. Oceanogr. 36, 424-432. http://dx.doi.org/10.4319/lo.1991.36.3.0424.

Lang, N., Wolff, E.W., 2011. Interglacial and glacial variability from the last 800 ka in marine, ice and terrestrial archives. Clim. Past 7, 361-380.

Latimer, J.C., Filippelli, G.M., 2001. Terrigenous input and paleoproductivity in the Southern Ocean. Paleoceanography 16, 627-643.

Lefèvre, D., Minas, H.J., Minas, M., Robinson, C., Williams, P.J.L., Woodward, E.M.S., 1997. Review of gross community production, primary production, net community production and dark community respiration in the Gulf of Lions. Deep-Sea Res. II Top. Stud. Oceanogr. 44, 801-832.

Lisiecki, L.E., Raymo, M.E., 2005. A Pliocene-Pleistocene stack of 57 globally distributed benthic d180 records. Paleoceanography 20, PA1003.

Lukkari, K., Leivuori, M., Hartikainen, H., 2007. Fractionation of sediment phosphorus revisited: II. Changes in phosphorus fractions during sampling and storing in the presence or absence of oxygen. Limnol. Oceanogr. Methods 5, 445-456.

März, C., Poulton, S.W., Wagner, T., Schnetger, B., Brumsack, H.-J., 2014. Phosphorus burial and diagenesis in the central Bering Sea (Bowers Ridge, IODP Site U1341): perspectives on the marine P cycle. Chem. Geol. 363, 270-282.

McManus, J.F., Oppo, D.W., Cullen, J.L., 1999. A 0.5-million-year record of millennialscale climate variability in the North Atlantic. Science 283, 971-975.

Meyers, P.A., 1994. Preservation of elemental and isotopic source identification of sedimentary organic matter. Chem. Geol. 114, 289-302.

Millot, C., 1990. The Gulf of Lions' hydrodynamics. Cont. Shelf Res. 10, 885-894.

Morel, A., André, J.-M., 1991. Pigment distribution and primary production in the western Mediterranean as derived and modeled from coastal zone color scanner observations. J. Geophys. Res. 96, 12685-12698.

Murat, A., 1999. 41. Pliocene-Pleistocene occurrence of sapropels in the western Mediterranean Sea and their relation to eastern Mediterranean sapropels. In: Proceedings of the Ocean Drilling Program. Scientific Results. 161, pp. 519-527.

Passier, H.F., Middelburg, J.J., de Lange, G.J., Böttcher, M.E., 1997. Pyrite contents, microtextures, and sulfur isotopes in relation to formation of the youngest eastern Mediterranean sapropel. Geology 25, 519-522.

Passier, H.F., Middelburg, J.J., de Lange, G.J., Böttcher, M.E., 1999. Modes of sapropel formation in the eastern Mediterranean: some constraints based on pyrite properties. Mar. Geol. 153, 199-219.

Peterson, G.S., Ankley, G.T., Leonard, E.N., 1996. Effect of bioturbation on metal-sulfide oxidation in surficial freshwater sediments. Environ. Toxicol. Chem. 15, 2147-2155.

Pratt, L.M., 1984. Influence of paleoenvironmental factors on preservation of organic matter in Middle Cretaceous Greenhorn Formation, Pueblo, Colorado. Am. Assoc. Pet. Geol. Bull. 68, 1146-1159.

Pujol, C., Grazzini, C.V., 1995. Distribution patterns of live planktic foraminifers as related to regional hydrography and productive systems of the Mediterranean Sea. Mar. Micropaleontol. 25, 187-217.

Rabineau, M., Berné, S., Aslanian, D., Olivet, J.L., Joseph, P., Guillocheau, F., Bourillet, J.F., Ledrezen, E., Granjeon, D., 2005. Sedimentary sequences in the Gulf of Lion: a record of 100,000 years climatic cycles. Mar. Pet. Geol. 22, 775-804. http://dx.doi. 
org/10.1016/j.marpetgeo.2005.03.010

Raymont, J.E., 1980. Plankton \& Productivity in the Oceans: Volume 1: Phytoplankton. Elsevier.

Rodrigo-Gámiz, M., Martínez-Ruiz, F., Jiménez-Espejo, F.J., Gallego-Torres, D., NietoMoreno, V., Romero, O., Ariztegui, D., 2011. Impact of climate variability in the western Mediterranean during the last 20,000 years: oceanic and atmospheric responses. Quat. Sci. Rev. 30, 2018-2034.

Rogerson, M., Cacho, I., Jimenez-Espejo, F., Reguera, M.I., Sierro, F.J., Martinez-Ruiz, F., Frigola, J., Canals, M., 2008. A dynamic explanation for the origin of the western Mediterranean organic-rich layers. Geochem. Geophys. Geosyst. 9, Q07U01.

Rubio, A., Taillandier, V., Garreau, P., 2009. Reconstruction of the Mediterranean northern current variability and associated cross-shelf transport in the Gulf of Lions from satellite-tracked drifters and model outputs. J. Mar. Syst. 78, S63-S78.

Ruttenberg, K.C., 1992. Development of a sequential extraction method for different forms of phosphorus in marine sediments. Limnol. Oceanogr. 37, 1460-1482.

Ruttenberg, K.C., 1993. Reassessment of the oceanic residence time of phosphorus. Chem. Geol. 107, 405-409.

Ruttenberg, K.C., 2003. The global phosphorus cycle. In: Treatise on Geochemistry. 8. pp. 585-643.

Ruttenberg, K.C., Goñi, M.A., 1997. Phosphorus distribution, C:N:P ratios, and $813 \mathrm{Coc}$ in arctic, temperate, and tropical coastal sediments: tools for characterizing bulk sedimentary organic matter. Mar. Geol. 139, 123-145.

Sánchez Goñi, M., Cacho, I., Turon, J., Guiot, J., Sierro, F., Peypouquet, J., Grimalt, J. Shackleton, N., 2002. Synchroneity between marine and terrestrial responses to millennial scale climatic variability during the last glacial period in the Mediterranean region. Clim. Dyn. 19, 95-105.

Schenau, S.J., De Lange, G.J., 2001. Phosphorus regeneration vs. burial in sediments of the Arabian Sea. Mar. Chem. 75, 201-217.

Schenau, S.J., Reichart, G.-J., De Lange, G.J., 2005. Phosphorus burial as a function of paleoproductivity and redox conditions in Arabian Sea sediments. Geochim. Cosmochim. Acta 69, 919-931.

Shapiro, J., 1967. Induced rapid release and uptake of phosphate by microorganism. Science 155, 1269-1271.

Sierro, F.J., Flores, J.A.T., Baraza, J., 1999. Late glacial to recent paleoenvironmental changes in the Gulf of Cadiz and formation of sandy contourite layers. Mar. Geol. $155,157-172$.

Sierro, F.J., Hodell, D.A., Curtis, J.H., Flores, J.A., Reguera, I., Colmenero-Hidalgo, E. Bárcena, M.A., Grimalt, J.O., Cacho, I., Frigola, J., Canals, M., 2005. Impact of iceberg melting on Mediterranean thermohaline circulation during Heinrich events. Paleoceanography 20, PA2019.
Sierro, F.J., Andersen, N., Bassetti, M.A., Berne, S., Canals, M., Curtis, J.H., Dennielou, B., Flores, J.A., Frigola, J., Gonzalez-Mora, B., Grimalt, J.O., Hodell, D.A., Jouet, G., Perez-Folgado, M., Schneider, R., 2009. Phase relationship between sea level and abrupt climate change. Quat. Sci. Rev. 28, 2867-2881.

Sirocko, F., Lange, H., 1991. Clay-mineral accumulation rates in the Arabian Sea during the late Quaternary. Mar. Geol. 97, 105-119.

Slomp, C.P., Van Cappellen, P., 2007. The global marine phosphorus cycle: sensitivity to oceanic circulation. Biogeosciences 4, 155-171.

Slomp, C.P., Thomson, J., de Lange, G.J., 2002. Enhanced regeneration of phosphorus during formation of the most recent eastern Mediterranean sapropel (S1). Geochim. Cosmochim. Acta 66, 1171-1184.

Slomp, C.P., Thomson, J., de Lange, G.J., 2004. Controls on phosphorus regeneration and burial during formation of eastern Mediterranean sapropels. Mar. Geol. 203, 141-159.

Spears, D.A., Kanaris-Sotiriou, R., 1976. Titanium in some Carboniferous sediments from Great Britain. Geochim. Cosmochim. Acta 40, 345-351.

Strickland, J.D.H., Parsons, T.R., 1972. A Practical Handbook of Seawater Analysis: Ottawa: Fisheries Research Board of Canada. 167. pp. 45-64.

Suess, E., 1981. Phosphate regeneration from sediments of the Peru continental margin by dissolution of fish debris. Geochim. Cosmochim. Acta 45, 577-588.

Thamban, M., Rao, V.P., Schneider, R.R., Grootes, P.M., 2001. Glacial to Holocene fluctuations in hydrography and productivity along the southwestern continental margin of India. Palaeogeogr. Palaeoclimatol. Palaeoecol. 165, 113-127.

Thomson, J., Wilson, T.R.S., Culkin, F., Hydes, D.J., 1984. Non-steady state diagenetic record in eastern equatorial Atlantic sediments. Earth Planet. Sci. Lett. 71, 23-30.

Toerien, D.F., Gerber, A., Lötter, L.H., Cloete, T.E., 1990. Enhanced biological phosphorus removal in activated sludge systems. In: Advances in Microbial Ecology. Springer, pp. $173-230$.

Tyrrell, T., 1999. The relative influences of nitrogen and phosphorus on oceanic primary production. Nature 400, 525-531.

Tzedakis, P.C., McManus, J.F., Hooghiemstra, H., Oppo, D.W., Wijmstra, T.A., 2003. Comparison of changes in vegetation in northeast Greece with records of climate variability on orbital and suborbital frequencies over the last 450,000 years. Earth Planet. Sci. Lett. 212, 197-212.

Van Cappellen, P., Ingall, E.D., 1994. Benthic phosphorus regeneration, net primary production, and ocean anoxia: a model of the coupled marine biogeochemical cycles of carbon and phosphorus. Paleoceanography 9, 677-692.

Waelbroeck, C., Labeyrie, L., Michel, E., Duplessy, J.C., McManus, J.F., Lambeck, K., Balbon, E., Labracherie, M., 2002. Sea-level and deep water temperature changes derived from benthic foraminifera isotopic records. Quat. Sci. Rev. 21, 295-305. 